\title{
DAMPAK TEKNOLOGI ATAS NILAI-NILAI SOSIAL PADA TRADISI BEKARANG SEBAGAI SUMBER PENCIPTAAN KARYA TARI SANGKUT DAK MENYAUH
}

\author{
Suaida, Susas Rita Loravianti, Eduard Zebua \\ Program Pascasarjana Institut Seni Indonesia Padangpanjang \\ Email: suaida9@gmail.com, HP: 085270525800
}

\begin{abstract}
The dance work entitled "Sangkut Dak Menyauh" is inspired by the Bekarang tradition of the Muaro Jambi community. Bekarang tradition is a fishing tradition that is carried out jointly by using tangkul, lukah, jalo. Bekarang has become one of the community traditions that must be preserved, but along with the development of the times this tradition has changed, due to the capture factor that utilizes technology with various cheats to meet human interests practically so that it can damage fish habitats and the wider environment. The instructor interpreted the impact of technology on influencing social values in the Bekarang tradition as a personal expression in the form of contemporary dance with an abstract type of environmental theme that conveys social values. The methods of creation include feeling, research, exploration of the nature of the center, improvisation, formation, and evaluation. The work consists of three parts. First abstracting the behavior of humans who abuse technology against living things. Second, how technology destroys living things. These three symbols are ritual values.
\end{abstract}

Keywords: Sangkut Dak Menyauh, contemporary, tradition bekarang, technological impact, social value.

\begin{abstract}
ABSTRAK
Karya tari yang berjudul "Sangkut Dak Menyauh" terinspirasi dari tradisi Bekarang masyarakat Muaro Jambi. Tradisi Bekarang merupakan sebuah tradisi penangkapan ikan yang dilakukan secara bersama-sama dengan menggunakan tangkul, lukah, jalo. Bekarang menjadi salah satu tradisi masyarakat yang harus dilestarikan, namun seiiring dengan perkembangan zaman tradisi ini mengalami perubahan, yang disebabkan faktor penangkapan yang memanfaatkan teknologi dengan berbagai kecurangan untuk memenuhi kepentingan manusia secara praktis sehingga dapat merusak habitat ikan dan lingkungan lebih luas. Pengkarya menginterpretasikan dampak teknologi memengaruhi nilai sosial dalam tradisi Bekarang sebagai ekspresi personal dalam bentuk tari kontemporer dengan tipe abstrak tema lingkungan yang menyampaikan nilai-nilai sosial. Metode penciptaan diantaranya merasakan, riset, eksplorasi sifat sentrum, improvisasi, pembentukan, dan evaluasi. Karya terdiri dari tiga bagian. Pertama mengabstraksikan tingkah laku manusia yang menyalahgunakan teknologi terhadap makhluk hidup. Kedua bagaimana teknologi menghancurkan makhluk hidup. Ketiga simbol nilai ritual.
\end{abstract}


Kata kunci: sangkut dak menyauh, kontemporer, tradisi bekarang, dampak teknologi, nilai sosial.

\section{PENDAHULUAN}

Muaro Jambi khusunya di Desa Arang-arang memiliki sebuah tradisi yang sudah turun-temurun, yaitu tradisi Bekarang. Bekarang merupakan tradisi masyarakat dalam menangkap ikan, yang dilakukan secara bersama-sama dengan menggunakan tangkul, lukah, jalo, dan ngecal (Mizun, wawancara, 31 Agustus 2019). Pengertian Bekarang disampaikan oleh Mizun, sejalan dengan apa yang disampaikan oleh Syahrial De Saputra (2012:31), mengatakan Bekarang merupakan sebuah tradisi penangkapan ikan secara bersama-sama di lubuk larangan Danau Arang-arang.

Tradisi Bekarang menjadi suatu tradisi kepercayaan (animatisme) yang tumbuh dan berkembang secara alami berdasarkan pengalaman hidup yang mereka hadapi dari dahulu hingga sekarang. Menurut kepercayaan masyarakat setempat, pada dahulunya di Danau Arang-arang ada makhluk disebut transplajo. Transplajo merupakan sebuah batang kayu bulian rubuh ke dalam danau, sekian tahun lamanya terbenam sehingga kedalamanya berpuluh meter. Semejak kayu ini terbenam air dari danau tidak pernah kering meskipun pernah terjadi musim kemarau selama tujuh bulan. Ketika malam hari tiba pun, transplajo mengeluarkan aroma berbau kencur yang diyakini sebagai penunggu Danau Arang-arang (raja ikan). Pada masa itu ada pengulu Pinge, orang yang dituakan untuk memuja makhluk-makhluk halus. Dengan melalui makhluk halus yang ada ikanikan dapat dipanggil dan berkumpul pada suatu tempat sehingga memudahkan untuk menangkapnya, tetapi pada masa sekarang pengulu Pinge sudah digantikan dengan Imam yang dituakan oleh masyarakat setempat.

Bekarang menjadi salah satu tradisi masyarakat Muaro Jambi, khususnya Desa Arang-arang yang harus dilestarikan secara turuntemurun. Namun seiiring dengan perkembangan zaman tradisi ini setiap tahunnya mengalami perubahan, karena ikan yang didapatkan mulai bekurang. Hal ini disebabkan adanya faktor penangkapan ikan sudah dipengaruhi penangkapannya, dengan cara menangkap yang sudah tidak mengandalkan lagi cara-cara seperti yang lazim digunakan masyarakat, saat proses ritual satu tahun sekali. Di luar proses ritual yang dilakukan dalam satu tahun sekali, proses penangkapan ikan dilakukan dengan menggunakan sentruman ikan, memakai bahan-bahan kimia beracun, dan pledak ikan.

Proses penangkapan seperti ini bertujuan untuk memenuhi kepentingan pribadi manusia yang ingin memanfaatkan sumber daya alam (makhluk hidup) secara praktis dan lebih mudah. Dengan melakukan berbagai kecurangan dapat merusak habitat ikan dan lingkungan lebih luas, bahkan berdampak menghabiskan atau mempunahkan bibit ikan yang akan tumbuh, sehingga ikan yang didapatkan pertahun mulai berkurang dan perairan tempat Bekarang pun 
mulai tercemar oleh bahan-bahan kimia. Manusia tidak bertanggung jawab inilah menyebabkan tradisi Bekarang mulai mengalami perubahan dan memberikan dampak terhadap nilai sosial seperti memudarnya rasa kebersamaan, berkurangnya silahturahmi, lebih mementingkan diri sendiri (individual), merosotnya nilai moral, tidak pernah merasa puas, materialisme, sikap atau prilaku yang negatif, serta terkikisnya nilai-nilai tradisi setempat.

Berdasarkan persoalan dan fenomena di atas pengkarya terinspirasi untuk menciptakan karya seni berbasis riset yang menginterpretasikan dampak teknologi memengaruhi nilai sosial dalam tradisi Bekarang sebagai ekspresi personal, tari kontemporer dengan tipe abstrak dan tema lingkungan. Tujuan karya "Sangkut Dak Menyauh" untuk memberikan himbauan kepada masyarakat atas sikap atau prilaku yang menyalahgunakan teknologi untuk memperdaya makhluk hidup, akan memberikan dampak terhadap lingkungan dan perubahan nilai sosial budaya. Selain itu melalui karya yang diciptakan pengkarya berharap dapat memberikan manfaat serta informasi bagi masyarakat umum, bahwa adanya tradisi Bekarang atau tradisi menangkap ikan yang masih berkembang di Muaro Jambi khususnya Desa Arang-arang. Memberikan pemahaman terhadap masyarakat untuk tidak menyalahgunakan teknologi, sebab teknologi bukanlah hambatan atau penghalang untuk memperkaya budaya. Namun teknologi justru menjadi perantara dalam meningkatkan dan melestarikan budaya. Semua tergantung pada penggunanya, bagaimana pengguna tersebut membawa teknologi apakah kearah yang positif atau negatif. Sebagai bahan referensi bagi kreator seni untuk meningkatkan daya imajinasi dan bagaimana memanfaatkan atau mengembangkan sumber pijakan berlatar belakang tradisi. Menjadi sumbangan penciptaan seni tari yang bersumber dari persoalan tradisi Bekarang di Desa Arang, secara teoritik menggunakan komposisi kontemporer.

\section{STUDI LITERATUR}

Umumnya sebuah karya seni muncul dengan adanya inspirasi dan imajinasi serta referensi karya-karya sebelumnya, dan sumber lain yang menjadi pedoman. Sumber tersebut bisa berbentuk buku, audio visual, bahkan pengalaman pribadi pengkarya sendiri. Adapun referensi dan sumber yang menjadi acuan pengkarya, yakni terinspirasi dari pengalaman pribadi pengkarya, dimana pengkarya pernah mengikuti tradisi Bekarang ini menjadi inspirasi pengkarya untuk menciptakan sebuah karya tari berlatar belakang tradisi masyarakat dan mencari informasiinformasi lainnya.

$\begin{array}{lcc}\begin{array}{c}\text { Laporan } \\ \text { Maimbau" }\end{array} & \begin{array}{c}\text { Karya tari } \\ \text { koreografer }\end{array} & \begin{array}{c}\text { "Pasia } \\ \text { Erwin }\end{array} \\ \text { Mardiansyah } & \text { (2018), karya } & \text { tari ini } \\ \text { terinspirasi } & \text { dari } & \text { prilaku }\end{array}$
penyimpangan masyarakat terhadap ikan bilih di Danau Singkarak, tari kontemporer dengan tipe dramatik dan tema lingkungan hidup. Struktur garapan Erwin Mardiansyah menggambarkan akitivitas masyarakat menangkap ikan bilih serta konflik penyimpangan yang dilakukan oleh masyarakat berdampak negatif. Karya ini memiliki kesamaan dalam bentuk 
ketertarikan, karena pengkarya samasama prihatin terhadap penyimpangan yang dilakukan oleh masyarakat saat ini yang berdampak negatif. Perbedaannya dapat dilihat dari karya "Sangkut Dak Menyauh" terinspirasi dari dampak teknologi memengaruhi nilai sosial dalam tradisi Bekarang sebagai ekspresi personal dalam bentuk tari kontemporer, dengan menggunakan tipe abstrak dan tema lingkungan. Struktur garapan karya menggambarkan simbol-simbol dari kontemplasi pengkarya terhadap fenomena tersebut.

Karya tari "Mutualisme" koreografer Lovia Triyuliani (2019), karya tari ini terinspirasi dari tradisi Kayek atau jamban di Jambi dengan koreografi mengungkapkan pengalaman empirik terhadap fenomena sosial dari aktifitas dan karakter masyarakat di jamban, dalam bentuk karya tari kontemporer berbasis idiom lokal. Karya ini memiliki kesamaan dalam bentuk karya tari kontemporer berbasis idiom lokal, tetapi dalam penggarapan karya tentu berbeda Lovia Triyuliani mencoba mendekatkan kontemporer dengan idiom tari zapin, sedangkan karya "Sangkut Dak Menyauh" mendekatkan kontemporer dengan idiom tari kubu.

Karya tari "Kota, Limbah Dan Sungai Musi" koreografer Sonia Anisah Utami (2018), karya tari ini terinspirasi dari kehidupan pinggiran di Sungai Musi. Yang memfokuskan keprihatinan pengkarya melihat realitas lingkungan tentang fenomena limbah dikawasan kumuh pinggiran Sungai Musi dan mengungkapkan nilai sosial. Karya ini memiliki kesamaan yaitu sama-sama prihatin terhadap perubahan nilai sosial masyarakat yang memberikan dampak negatif bagi lingkungan. Perbedaannya karya "Sangkut Dak Menyauh" terinspirasi dari dampak teknologi memengaruhi nilai sosial dalam tradisi Bekarang dengan alur garapan memakai alur campuran (maju mundur), sedangkan alur garapan Sonia Anisah Utami memakai alur maju.

Membaca buku yang berjudul "Tradisi Bekarang Muaro Jambi" oleh Syahrial De Saputra (2012), tentang perkembangan tradisi Bekarang dari zaman dahulu sampai sekarang. Wawancara dengan Ibu Rosmina dan Bapak Ipul pada 08 Oktober 2018, mendapatkan informasi serta melihat secara langsung kecurangan yang dilakukan dalam Bekarang di Desa Sungai Kelemak. Wawancara dengan Bapak Mizun, Bapak Mulyadi, dan Abang Ridwan pada tanggal 31 Agustus 2019, melalui wawancara dan diskusi tersebut pengkarya dapat melihat, merasakan, serta mengikuti secara langsung proses tahapan ritual yang dilakukan satu tahun sekali di danau Arang-arang, Kecamatan Kumpe Ulu, Muaro Jambi.

\section{METODE}

Proses kekaryaan ini melalui enam tahapan, yakni: (1) Merasakan, yakni melihat objek, menyerap, dan merasakannya secara mendalam; (2) Riset yang dilakukan di Desa Arangarang, Kecamatan Kumpe Ulu, Kabupaten Muaro Jambi; (3) Eksplorasi, yakni penjajaan objek atau fenomena sebagai rangsangan untuk menemukan gerakan-gerakan yang sesuai dengan ide garapan; (4) Improvisasi, yakni proses penemuan gerak; (5) Tahap pembentukan (forming) atau komposisi, yang merupakan tahap transformasi bentuk gerak menjadi sebuah tarian atau 
koreografi; dan (6) Evaluasi, yakni proses menilai hasil latihan.

\section{HASIL DAN PEMBAHASAN}

\subsection{Ide Garapan}

Ide dalam pengkaryaan ini terinspirasi dari tradisi Bekarang Muaro Jambi. Hadirnya karya bersumber dari adanya persoalanpersoalan mengenai perubahan yang terjadi dalam tradisi Bekarang. Bekarang menjadi salah satu tradisi masyarakat yang seharusnya dilestarikan secara turun-temurun, tetapi pada saat ini manusia mencoba melakukan penyalah gunaan pemanfaatan teknologi terhadap tradisi Bekarang untuk kepentingan dirinya sendiri, dengan cara menyentrum ikan, memakai bahanbahan kimia beracun, dan pledak ikan yang dapat merusak habitat ikan dan lingkungan yang lebih luas. Sebab Bekarang bukan menuba atau bukan memanen membunuh masal ikan-ikan. Pemanfaatan teknologi ini seharusnya lebih meningkatkan dan mempermudah bukan menjadi hambatan yang dapat merusak atau menghancurkan.

Tradisi Bekarang sangat memberikan nilai-nilai sosial budaya untuk masyarakat setempat dan masih sangat relevan dengan masa kekinian. Persoalan ini menjadi rangsangan terhadap terciptanya karya tari "Sangkut Dak Menyauh" dengan bentuk ungkapan ekspresi personal, yang digarap berdasarkan interpretasi terhadap pengalaman empirik serta cara pandang pengkarya, melihat persoalan tentang dampak teknologi memengaruhi nilai sosial dalam tradisi Bekarang, tari kontemporer berdurasi \pm 40 menit. Eko Pece (2018: 9) mengatakan, kontemporer merupakan kompleksitas ekspresi yang lebih pada gerakan yang membutuhkan kebebasan. Tari kontemporer tidak hanya merujuk pada bentuk produk karya tari, tetapi terdapat ide karya yang terelaborasi ke dalam proses penciptaan melalui pendekatan persoalan masing-masing koreografer.

\subsection{Judul Karya}

Judul karya "Sangkut Dak Menyauh" yang artinya terjerat tetapi tidak berisi. Pengkarya menginterpretasikan "Sangkut Dak Menyauh" sebagai suatu harapan untuk mendapatkan hasil ikan yang memuaskan saat melakukan tradisi Bekarang, tetapi harapan jauh dari perkiraan, karena perangkap ikan yang sudah dipasang sama sekali tidak berisi. Penyalahgunaan pemanfaatan teknologi oleh manusia inilah menjadi penyebab perubahan yang terjadi. Tema tari yaitu lingkungan. Menurut KBBI "lingkungan" adalah daerah, kawasan dan sebagainya yang termasuk didalamnya (KBBI edisi keempat, 2008: 831). Dari definisi di atas pemilihan tema lingkungan yang dimaksud yakni, tentang persoalan tradisi Bekarang yang mengungkapkan budaya masyarakat Muaro Jambi yang kurang menyadari dampak penyalahgunaan teknologi dari perbuatannya. Sehinga dapat merusak habitat dan lingkungan yang lebih luas, bahkan berdampak menghabiskan atau mempunahkan bibit ikan yang akan tumbuh.

\subsection{Tipe Garapan}

Tipe dalam penggarapan karya menggunakan tipe abstrak, yang tidak menceritakan sebuah alur cerita, tetapi hanya menghadirkan cuplikancuplikan sederhana yang berangkat 
dari tradisi Bekarang. Alur karya tari memiliki alur campuran (maju mundur). Dasar gerak karya "Sangkut Dak Menyauh" berpijakan kepada tari kubu Jambi, dengan memakai idom gerak bertumpu pada gerakan kaki, tangan mengayun, badan mengayun, dan pola ruang gerak yang sempit. Selain itu pijakan gerak bersumber dari pola laku, prilaku, dan tingkah laku masyarakat yang menyalahgunakan teknologi, disimbolkan dengan gerak dari sifat sentruman (kejang, berdenyut sesekali, dan sesak nafas). Penari sebanyak tujuh orang penari perempuan dan dua penari laki-laki.

Musik dalam penggarapan karya "Sangkut Dak Menyauh" menggunakan tekno live. Musik bagian satu, tekno live dengan bisikan dari vokal dusun yang rimbo, sunge yang tenang, ikane jinak, dalam perangkap. Musik bagian dua, memakai instrumen perkusi yang memainkan dinamika musik menyimbolkan keterjeratan, keterkurungan dan keterperangkapan. Musik bagian tiga, suasana ritual dengan menggunakan instrumen kulintang dan Krinok yang diiringi biola serta vokal oii sialang belantak besi, rantau begelar lubuk benamo, iyolah lubuk yang dalam silubuk panjang, gena ikan berenang rindang dalam lebung, penghujung pualam singgahlah sangsai, melenggang gersang erengi aek aek sunge, tunjukku serio jadi, baliku balikan aek yang surut, tangkul tejerang ikane jinak, sangkut sengarat idak menyauh, mencacak serampang tak keno jadi.

Kostum yang digunakan adalah baju sepanjang lutut dan celana pendek bewarna kuning diberi bis jaring-jaring hitam, sebagai simbol jaring penangkap ikan dan lampu LAD yang dibalut dengan bis hijau sebagai simbol sirip ikan, lumut air, dan sebagai keterikatan tubuh ikan terhadap penyalahgunaan teknologi. Sedangkan dilihat dari segi rias wajah natural minimalis dan terkesan tajam dengan memadukan eyeshadow berwarna gelap hitam dan coklat, rambut dijalin gerai berbeda-beda. Tata cahaya yang digunakan akan didominasi dengan lampu general, lampu filter, dan lampu fokus yang disesuaikan dengan kebutuhan karya.

Penggunaan property dan setting, bagian satu menggunakan property dan setting siluet berbias cahaya seperti perangkap, kain sifon berwarna putih yang menyimbolkan air atau ruang tempat makhluk hidup dan lampu LAD hijau sebagai sirip ikan atau berlumut. Bagian dua menggunakan empat kotak persegi panjang dengan posisi bambu yang berdiri menyilang dan tidak sama bentuknya sebagai ruang perangkap. Bagian tiga menggunakan tujuh lukah berukuran sedang sebagai simbol alat penangkapan ikan. Karya tari dipertunjukan di Gedung Pertunjukan Hoeridjah Adam Institut Seni Indonesia Padangpanjang.

\subsection{Proses Berkarya}

\section{Merasakan}

Merasakan merupakan suatu tahapan yang melihat objek, menyerap, dan merasakan secara mendalam, menjadikan sadar akan sensasi dalam diri yang berkaitan dengan objek tradisi Bekarang di Muaro Jambi khususnya Desa Arangarang.

\section{Riset}

Riset yang dilakukan yaitu melakukan riset lapangan di Desa Arang-arang, Kecamatan Kumpe Ulu, Kabupaten Muaro Jambi. Pada tahap 
pertama pengkarya melihat langsung terjadinya konflik permasalahan dalam tradisi Bekarang, yang mana masyarakat melakukan penangkapan ikan dengan cara menyentrum ikan, memakai bahan kimia beracun, dan pledak ikan. Tahap kedua mengamati, dan melakukan ritual tradisi Bekarang yang dilakukan dalam satu tahun sekali, serta berinteraksi langsung kepada bapak Mulyadi selaku Imam (tertua), Bapak Mizum selaku Kepala Desa Arang-arang, dan Abang Ridwan selaku Ketua Pemuda. Pada tahapan ini pengkarya banyak merasakan perubahan-perubahan yang terjadi dalam proses ritual tradisi Bekarang, hal ini dapat dilihat dari hasil ikan yang didapatkan sangat jauh berbeda dari tahun-tahun sebelumnya. Perubahan inilah yang menyebabkan munculnya ketertarikan pengkarya.

\section{Eksplorasi}

Eksplorasi yang dilakukan dalam proses penggarapan yaitu eksplorasieksplorasi penjajaan objek atau fenomena sebagai rangsangan untuk menemukan gerakan-gerakan yang sesuai dengan ide garapan, yang akan pengkarya ciptakan dalam karya tari "Sangkut Dak Menyauh". Eksplorasi termasuk memikirkan, mengimajinasikan, merenungkan, merasakan, dan juga merespon objekobjek atau fenomena alam yang ada $(\mathrm{Y}$ Sumandiyo Hadi, 2012:70). Tahap eksplorasi pertama pengkarya memikirkan, mengimajinasikan, merenungkan dan merasakan peristiwa yang menarik dari ritual tradisi Bekarang. Kedua setelah ide itu didapat pengkarya mencoba mengeksplor diri pengkarya sendiri dengan melakukan respon gerak tubuh terhadap benda atau alat penangkap ikan seperti lukah dan jalo, dengan mencari pola bentuk yang berbeda atau sulit dilakukan dari biasanya. Ketiga pengkarya mencoba mengeksplor gerakan yang menyimbolkan tentang dampak teknologi yang mempengaruhi nilai sosial dalam tradisi Bekarang ditafsirkan kedalam bentuk antara lain; (1) Sifat sentruman yang memberikan reaksi pada tubuh (kejang, berdenyut sesekali, dan sesak nafas); (2) Keterjeratan, keterkurungan, dan keterperangkapan mencari celah untuk keluar dengan pola gerak yang sempit; (3) Memainkan alur, ruang, dan waktu disaat mengeskplor property yang digunakan. Keempat pengkarya mengeksplor dari rangsangan auditif terhadap mantra dari tradisi Bekarang dengan pola gerak berbabasis idom lokal pada tari kubu (bertumpu pada gerakan tangan mengayun, hentakan kaki, dan pola badan mengayun). Kelima pengkarya mencoba mengeksplor penafsiran penyampaian pesan kekaryaan dalam bentuk vokal musik, yang berupa pesan-pesan dari karya itu sendiri dengan dipadukan musik Krinok.

\section{Improvisasi}

Improvisasi diartikan sebagai penemuan gerak secara kebetulan atau movement by chance, walaupun gerak-gerak tertentu muncul dari gerak-gerak yang pernah dipelajari atau ditemukan sebelumnya, tetapi ciri spontanitas menandai hadirnya tahap improvisasi (Y Sumandiyo Hadi, 2012:76). Setelah melakukan eksplorasi, pengkarya memberikan kebebasan kepada penari untuk berimprovisasi pada bagian-bagian tertentu untuk mendukung konsep garapan. Selain itu pengkarya juga memberikan dorongan motivasi agar 
penari mampu merespons dan membuat tindakan dalam bentuk gerak yang baru dan unik diluar dari kemampuan biasanya.

\section{Pembentukan}

Tahap pembentukan (forming) atau komposisi, merupakan tahap mentransformasikan bentuk gerak menjadi sebuah tarian atau koreografi (Y Sumandiyo Hadi, 2012:78). Setelah pengkarya melakukan tahap eksplorasi dan improvisasi, pengkarya mulai masuk pada tahap membentuk karya tari. Hasil eksplorasi dan improvisasi yang sudah pengkarya lakukan sebelumnya dituangkan kedalam pembentukan garapan. Karya tari akan digarap dengan tiga bagian, proses garapan dilakukan secara terstruktur dimulai dari kesatuan, variasi, kontinyuitas atau pengembangan, repetisi atau ulangan, transisi atau perpindahan, rangkaian, klimaks, dan keutuhan harmonis dan dinamis. Dari bentuk-bentuk gerak yang diberikan pengkarya mulai menyatukan bentuk-bentuk tersebut menjadi kalimat dalam gerak yang memberikan makna dan simbol terhadap konsep karya. Setelah itu bentuk-bentuk gerak ini disusun sesuai dengan bagian-bagian struktur garapan yang sudah dibuat dengan menambahkan transisi, sehingga peristiwa yang dihadirkan dapat menyampaikan maksud dari konsep karya.

Bagian Satu, mengabstraksikan tingkah laku manusia yang melakukan penyalahgunaan teknologi terhadap kehidupan makhluk hidup di air, suasana tegang. Adegan satu: menggambarkan kontemplasi pengkarya terhadap fenomena, yang diungkapkan melalui penari berdiri menggunakan siluet berbias cahayanya seperti terperangkap, dengan menyanyikan lirik vokal, dusun yang rimbo, sunge yang tenang, ikane jinak, dalam perangkap. Adegan dua: menggambarkan sifat sentruman ikan yang memberikan efek reaksi kepada tubuh dengan pola (kejangkejang, berdenyut, dan sesak nafas). Simbol memakai kain bewarna putih dan lampu LAD hijau yang ditafsirkan sebagai sirip ikan, berlumut, atau ikan yang sudah terperangkap oleh racun dari perbuatan manusia.

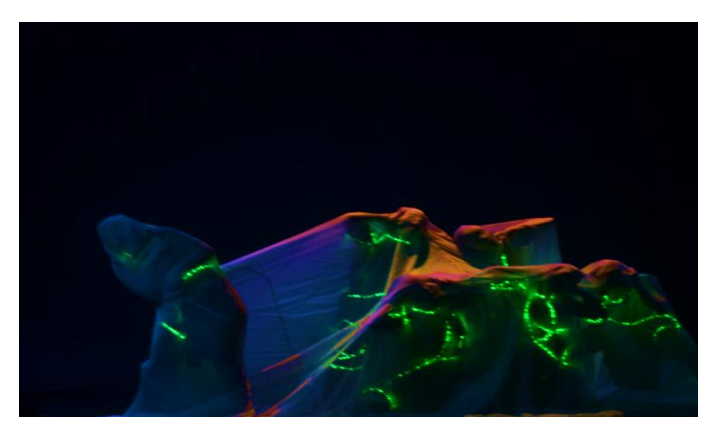

Gambar 1

Penari mencoba menafsirkan kehidupan makhluk hidup yang dipengaruhi penyalahgunaan teknologi (Foto : Suaida, 2019)

Bagian Dua, mengabstraksikan bagaimana teknologi menghancurkan kehidupan makhluk hidup di dalam air, suasana tegang. Adegan satu: menggambarkan terjerat, terkurung, terperangkap, seolah-olah hidupnya, dirinya, dan dunianya. Simbol memakai empat kotak persegi panjang dengan posisi bambu yang berdiri menyilang dan tidak sama bentuknya sebagai ruang perangkap atau bisa masuk tetapi keluar tidak. Adegan dua: menggambarkan usaha mencari celah untuk keluar, semakin lekat, terjebak dan menjadi semakin menyakitkan yang dapat membunuh dirinya sendiri. 


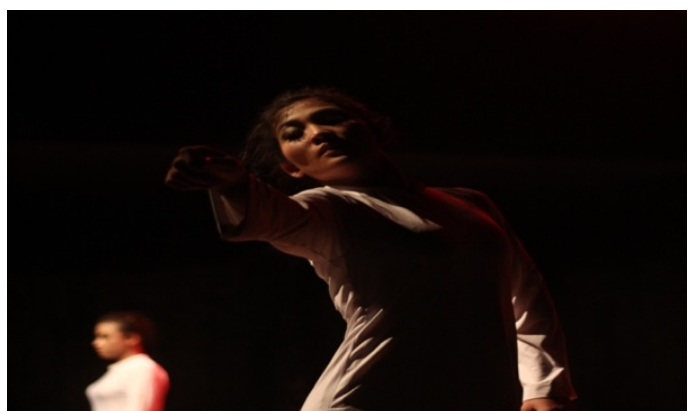

Gambar 2

Penari mencoba mengekspresikan keterperangkapan yang menyakitkan dapat membunuh dirinya sendiri

(Foto : Suaida, 2019)

Bagian Tiga, mengabstraksikan bagaimana usaha untuk mempertahankan nilai tradisi budaya, suasana tenang. Adegan satu: mengekspresikan nilai ritual ketika sebuah ritual dilakukan dalam tradisi Bekarang. Ritual ini menjadi pengikat yang tidak boleh dihilangkan. Divisualkan dengan pola gerak yang bertumpu pada gerak kaki, tangan mengayun, badan mengayun, dan pola ruang gerak yang sempit, serta diiringi Krinok. Adegan dua: mevisualisasikan bagaimana menyentuh atau menghimbau manusia bahwa nilai tradisi pada setiap budaya yang ada harus tetap dipertahankan secara bersama-sama. Walaupun sudah terjadinya perubahan nilai sosial yang diakibatkan oleh perbuatan manusia yang menyalahgunakan pemanfaatan teknologi untuk kepentingan dirinya sendiri dan tetap menjunjung tinggi nilai-nilai yang ada. Simbol dengan memakai tujuh lukah, diartikan sebagai alat penangkap ikan dalam tradisi Bekarang yang dijunjung tinggi secara bersama-sama.

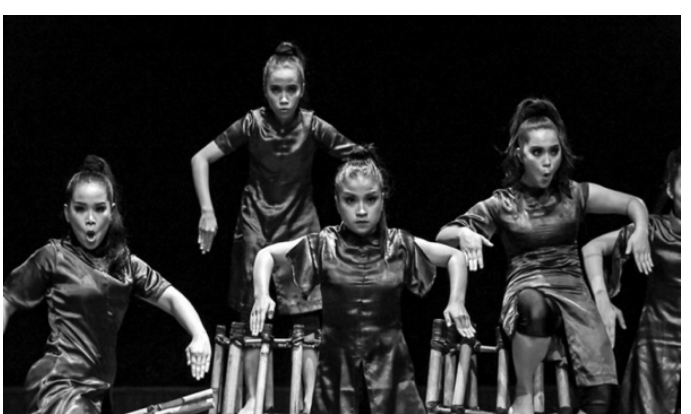

Gambar 3

Penari menyimbolkan nilai ritual

(Foto : Suaida, 2019)

\section{Evaluasi}

Melangkah mundur untuk melihat apa yang telah diciptakan atau menilai hasil kreativitas setelah selesainya sebuah garapan (Alma M. Hawkins, 2003:135). Setelah pengkarya melakukan tahap eksplorasi, improvisasi, dan pembentukan, pengkarya mulai menggunakan tahap evaluasi. Dimana pengkarya menilai hasil setiap latihan, apakah sudah sesuai dengan yang pengkarya harapkan atau belum. Selain itu pengkarya juga mengamati karya dan isian karya harus sesuai dengan laporan tulisan yang ingin disampaikan.

\section{KESIMPULAN}

Karya "Perangkap" merupakan sebuah karya tari yang terinspirasi dari tradisi Bekarang yang ada di Muaro Jambi. Bekarang merupakan sebuah tradisi masyarakat menangkap ikan yang dilakukan secara bersamasama, namun seiiring dengan perkembangan zaman tradisi ini mengalami perubahan, yang disebabkan faktor penangkapan yang memanfaatkan teknologi dengan berbagai kecurangan untuk memenuhi kepentingan manusia secara praktis, lebih mudah sehingga dapat merusak habitat ikan dan lingkungan lebih luas. Pengkarya 
menginterpretasikan dampak teknologi yang memengaruhi nilai sosial dalam tradisi Bekarang sebagai ekspresi personal dalam bentuk karya tari kontemporer yang berbasis idiom budaya lokal, dengan tipe abstrak dan tema budaya.

\section{DAFTAR PUSTAKA}

Hawkins, Alma M. (2003). Bergerak Menurut Kata Hati. Terjemahan I Wayan Dibia. Jakarta: Four Foundation.

Hawkins, Alma M. (2003). Creating Through Dance (Mencipta Lewat Tari. Terjemahan Y. Sumandiyo Hadi). Manthili Yogyakarta

Hasnah Sy. (2010). Pengetahuan Tari. Padangpanjang: Seri Buku Ajar

Saputra De Syahrial. (2012). Tradisi Bekarang Muaro Jambi. Tanjungpinang: Kementrian Kebudayaan dan Pariwisata Balai Pelstarian Sejarah dan Nilai Tradisional

Sardono W Kusumo. (2014). Sardono $W$ Kusumo Hanoman Tarzan Homo Erectus. Jakarta: Prenada Media Group

Smith, Jacqualine. (1985) "Dance Composition" A Practical Guide for Teachers ("Komposisi Tari" Sebuah Petunjuk Praktis bagi Guru. Terjemahan Ben Suharto). Yogyakarta: Ikalasti

Hadi, Sumandiyo Y. (2012). Koreografi Bentuk Teknik dan Isi. Yogyakarta: Cipta Media

Hadi, Y Sumandiyo. (2000). Seni dalam Ritual Agama. Yogyakarta: Yayasan Untuk Indonesia

Sumardjo, Jakob. (2002). Arkeologi Budaya Indonesia. Yogyakarta: Qalam
Sumaryono. (2003). Restorasi seni dan transformasi

budaya.Yogyakarta: lembaga kajian pendidikan

Williams Raymond, (2004). Teori Budaya dan Budaya Pop, terjemahan John Storey. Yogyakarta: Qalam

\section{DAFTAR INFORMAN}

Rosmina. (43 tahun). Pengakap ikan, alamat Desa Sungai Kelemak, Kelurahan Sengeti, Kabupaten Muaro Jambi, wawancara langsung pada 08 Oktober 2018

Ipul. (50 tahun). Pengakap ikan, alamat Desa Sungai Kelemak, Kelurahan Sengeti, Kabupaten Muaro Jambi, wawancara langsung pada 08 Oktober 2018

Muhammad Fazrianto. (34 tahun). Swasta, alamat Desa Senaung, Kabupaten Muaro Jambi, wawancara langsung pada 04 Februari 2014

Sukri. (43 tahun). Pengawas sekolah SMA 5 Kumpe Ulu, alamat Desa Arang-arang, Kecamatan Kumpe Ulu, Kabupaten Muaro Jambi, wawancara langsung pada 06 Februari 2019

Syafi'I. (53 tahun). Wiraswasta, alamat Desa Senaung, Kabupaten Muaro Jambi, wawancara langsung pada 24 Juli 2019

Mizun. (50 tahun). Kepala Desa Arangarang, alamat Desa Arangarang, Kecamatan Kumpe Ulu, Kabupaten Muaro Jambi, wawancara langsung pada 31 Agustus 2019

Mulyadi. (49 tahun). Tetua Desa Arang-arang, alamat Desa Arang-arang, Kecamatan Kumpe Ulu, Kabupaten Muaro 
Jambi, wawancara langsung pada 31 Agustus 2019

Ridwan. (32 tahun). Ketua pemuda Desa Arang-arang, alamat Desa Arang-arang, Kecamatan Kumpe Ulu, Kabupaten Muaro Jambi, wawancara langsung pada 31 Agustus 2019 